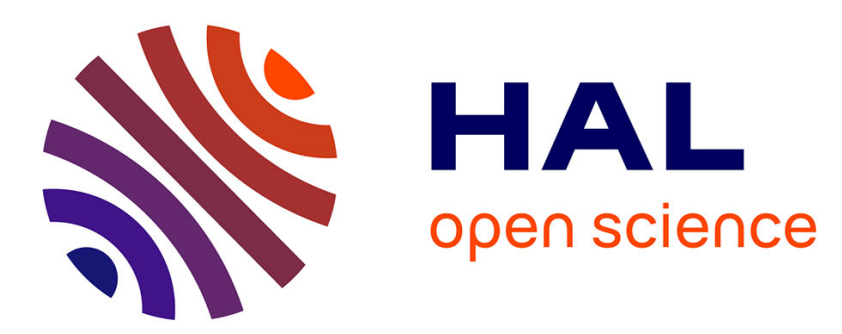

\title{
Exposure of fathead minnows to municipal wastewater effluent affects intracellular signaling pathways in the liver
}

Jennifer Arstikaitis, François Gagné, Daniel G. Cyr

\section{- To cite this version:}

Jennifer Arstikaitis, François Gagné, Daniel G. Cyr. Exposure of fathead minnows to municipal wastewater effluent affects intracellular signaling pathways in the liver. Comparative Biochemistry and Physiology - Part C: Toxicology and Pharmacology, 2014, 164, pp.1-10. 10.1016/j.cbpc.2014.04.002 . hal-01178760

\author{
HAL Id: hal-01178760 \\ https://hal.science/hal-01178760
}

Submitted on 21 Jul 2015

HAL is a multi-disciplinary open access archive for the deposit and dissemination of scientific research documents, whether they are published or not. The documents may come from teaching and research institutions in France or abroad, or from public or private research centers.
L'archive ouverte pluridisciplinaire $\mathbf{H A L}$, est destinée au dépôt et à la diffusion de documents scientifiques de niveau recherche, publiés ou non, émanant des établissements d'enseignement et de recherche français ou étrangers, des laboratoires publics ou privés. 


\section{Exposure of fathead minnows to municipal wastewater effluent affects intracellular signaling pathways in the liver}

ARTICLE in COMPARATIVE BIOCHEMISTRY AND PHYSIOLOGY PART C TOXICOLOGY \& PHARMACOLOGY · APRIL 2014

Impact Factor: $2.83 \cdot$ DOI: 10.1016/j.cbpc.2014.04.002 Source: PubMed

CITATION

1

3 AUTHORS, INCLUDING:

\section{François Gagné}

Environment Canada

170 PUBLICATIONS 3,732 CITATIONS

SEE PROFILE
DOWNLOADS

15
VIEWS

58
Daniel G Cyr

Institut national de la recherche scientifique 137 PUBLICATIONS 3,429 CITATIONS

SEE PROFILE 
Provided for non-commercial research and education use. Not for reproduction, distribution or commercial use.

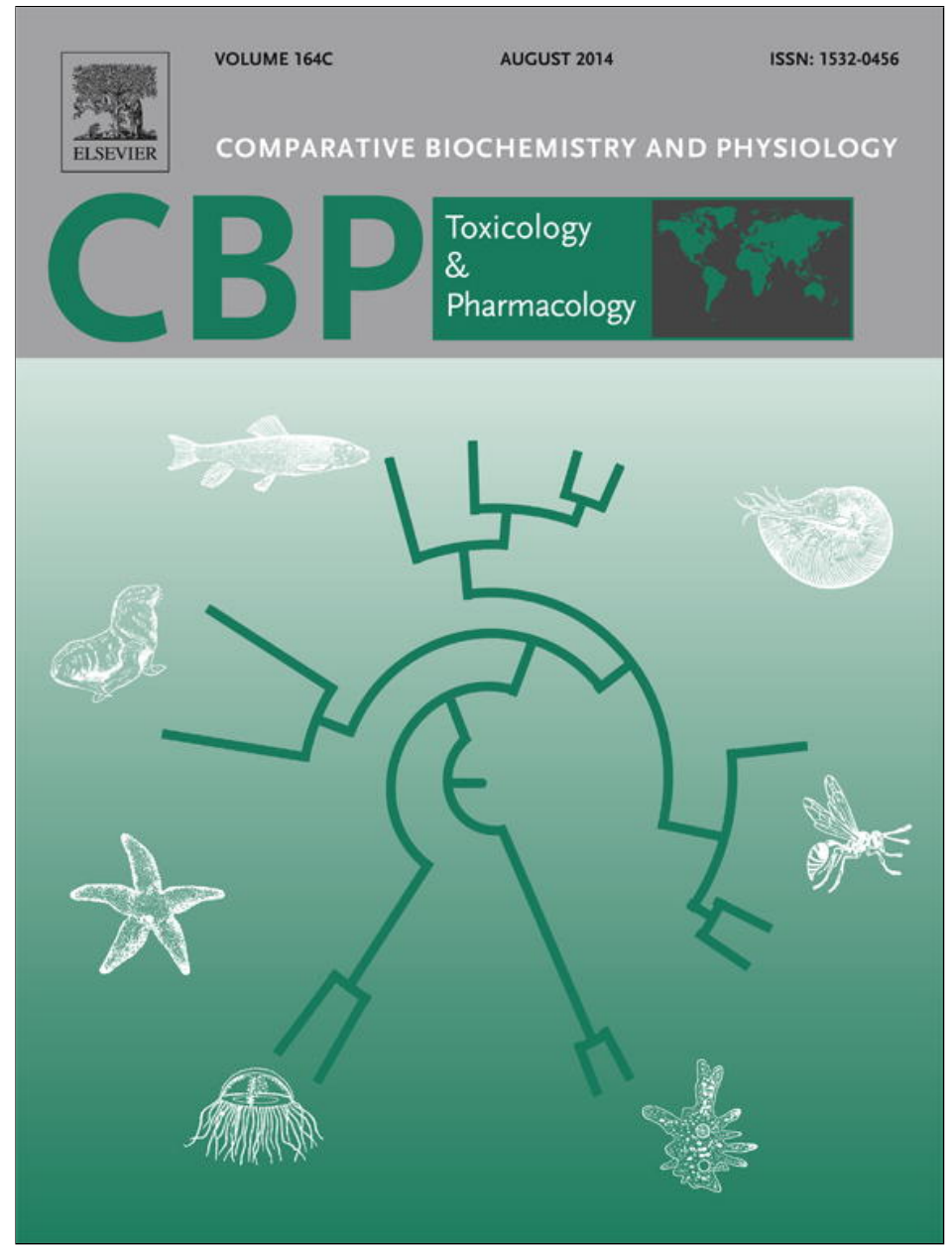

This article appeared in a journal published by Elsevier. The attached copy is furnished to the author for internal non-commercial research and education use, including for instruction at the authors institution and sharing with colleagues.

Other uses, including reproduction and distribution, or selling or licensing copies, or posting to personal, institutional or third party websites are prohibited.

In most cases authors are permitted to post their version of the article (e.g. in Word or Tex form) to their personal website or institutional repository. Authors requiring further information regarding Elsevier's archiving and manuscript policies are encouraged to visit:

http://www.elsevier.com/authorsrights 


\title{
Exposure of fathead minnows to municipal wastewater effluent affects intracellular signaling pathways in the liver
}

\author{
Jennifer Arstikaitis ${ }^{a}$, François Gagné ${ }^{a, b}$, Daniel G. Cyr ${ }^{\text {a,* }}$ \\ a INRS-Institut Armand-Frappier, Université du Québec, 531 Boulevard des Prairies, Laval, Québec H7V 1B7,Canada \\ b Centre Saint-Laurent, Environment Canada, Montreal, Québec H2Y 2E7, Canada
}

\section{A R T I C L E I N F O}

\section{Article history:}

Received 31 January 2014

Received in revised form 1 April 2014

Accepted 4 April 2014

Available online 16 April 2014

\section{Keywords:}

Microarray

Intracellular signaling

Liver

Fathead minnow

\begin{abstract}
A B S T R A C T
Municipal wastewater effluent can impact its receiving environment. In the St. Lawrence River, male fish living downstream from Montreal exhibit increased hepatic vitellogenin, intersex, delayed spermatogenesis and altered immune function. Few studies have examined genome-wide effects associated with municipal effluent exposure in fish to decipher the mechanisms of toxicity. The present objective was to identify hepatic cellular signaling pathways in fathead minnows following exposure to municipal wastewater effluent. Immature minnows were exposed for 21 days to either $0 \%$ (Control) or 20\% municipal effluent, the highest concentration in the St. Lawrence River. Hepatic RNA was extracted and used to hybridize a fathead minnow oligonucleotide microarray containing approximately $15 \mathrm{k}$ gene sequences. A total of 1300 genes were differentially expressed, of which 309 genes had more than 2-fold change in expression level between control and MWWE-exposed fish. Of those, 118 were up-regulated and 191 were down-regulated. Altered genes grouped according to function, indicated effects on various signaling pathways, apoptosis, immune responses, and cellular metabolism. Pathway analysis software predicted at least 5 signaling pathways that were altered by treatment: cell adhesion, inflammation, various kinases, estrogen receptor signaling and WNT signaling. Various components of the canonical Wnt pathway were dramatically down-regulated, while several other genes involved in the non-canonical Wnt pathway, such as Wnt4, LRP6, and PPP2R5E, which are known to inhibit the canonical Wnt pathway, were increased. These results indicate that municipal wastewater effluent from Montreal can target and inhibit various signaling including those implicated in hepatic Wnt signaling pathway in fathead minnows.
\end{abstract}

(c) 2014 Elsevier Inc. All rights reserved.

\section{Introduction}

There is well-established evidence of the deleterious impact of municipal wastewater effluent on fish living in the receiving aquatic environment (Jobling et al., 1998, 2002; Gregory et al., 2008; Thorpe et al., 2009; Vidal-Dorsch et al., 2012; Cyr et al., 2014). Sewage is collected from all municipalities on the island of Montreal, representing approximately 1.8 million people and approximately 8000 commercial establishments and industrial plants and is treated at the Montreal wastewater treatment plant (MWWTP) (Pham and Proulx, 1997; Sabik et al., 2003; Marcogliese et al., 2009). The MWWTP is among the largest primary physico-chemical treatment plant in North America (Sabik et al., 2003). This facility is located on the eastern tip of the island of Montreal and treats approximately 1.3 million $\mathrm{m}^{3}$ of raw wastewater daily (Pham and Proulx, 1997; Sabik et al., 2003; Marcogliese et al., 2009). During

\footnotetext{
* Corresponding author at: INRS-Institut Armand-Frappier, Université du Québec, 531 Boulevard des Prairies, Laval, Québec H7V 1B7, Canada. Tel.: + 1450687 5010x8833; fax: +1 4506865501 .

E-mail address: daniel.cyr@iaf.inrs.ca (D.G. Cyr).
}

periods of heavy rain or thaw, the volume of water can reach up to 7.6 million $\mathrm{m}^{3}$ (Pham and Proulx, 1997; Sabik et al., 2003; Marcogliese et al., 2009). Over $90 \%$ of Montreal wastewater effluent (MWWE) currently undergoes some form of wastewater treatment before reaching the St. Lawrence River (Chambers et al., 1997). This process includes mechanical screening, grit removal, a coagulant, usually ferric chloride, and an anionic polymer that are added to increase the settling of suspended particles (Chambers et al., 1997; Pham and Proulx, 1997; Gagné et al., 2002). Large particles are sieved and removed (Gagné et al., 2002) and the resulting effluent is released directly into the St. Lawrence River (Pham and Proulx, 1997; Sabik et al., 2003; Marcogliese et al., 2009).

Previous studies have shown that spottail shiners (Notropis hudsonius) caught in the St. Lawrence River downstream from the Montreal wastewater effluent discharge point displayed induced hepatic VTG (vitellogenin) mRNA levels, delayed spermatogenesis, produced fewer sperm that were less motile, and had a higher incidence of intersex (Aravindakshan et al., 2004). These fish also displayed suppressed immune function (Ménard et al., 2010) and altered parasitic abundance (Marcogliese et al., 2006). Recently, northern pike (Esox lucius) sampled downstream of the Montreal wastewater effluent 
outfall also had increased levels of hepatic VTG mRNA levels, as well as blood VTG levels as compared to fish sampled upstream (Houde et al., 2013). The fish also displayed increased gill metallothionein, superoxide dismutase, glutathion-S-transferase, and cytochrome P4501A1 (Cyp4501A1) levels, suggesting that metals or organic compounds from the effluent may result in the production of free radicals (Houde et al., 2013).

Short-term exposure of rainbow trout (Oncorhyncus mykiss) to this municipal effluent under laboratory conditions altered immune function and decreased thyroid function (Salo et al., 2007; Escarné et al., 2008). Long-term laboratory-based exposure studies, in which brook trout (Salvelinus fontinalis) were exposed to 1, 10 and 20\% MWWE concentrations for 4 and 12 weeks, indicated that hepatic VTG mRNA levels were unaltered after 4 weeks of treatment. However, VTG mRNA levels increased significantly at the two highest exposure concentrations at 12 weeks, suggesting that estrogenic compounds in the wastewater effluent likely accumulated over time (de Montgolfier et al., 2008). The expression of gap junction proteins, connexins, in the testes of these fish was also altered at both 4 and 12 weeks, which may, at least in part, explain the delayed spermatogenesis observed in wildcaught shiners in the St. Lawrence River downstream from Montreal (de Montgolfier et al., 2008). Rainbow trout hepatocyte primary cultures exposed in vitro to water samples collected $8 \mathrm{~km}$ downstream of the wastewater outfall displayed increased levels of metallothionein mRNA, Cyp1A1 enzyme activity, and increased cytotoxicity (Gagné and Blaise, 1995).

Together these studies clearly indicate that fish living downstream of the City of Montreal are negatively impacted by MWWE, and that these effects are directly related to contaminants present in the effluent. Still, there is limited information on the cellular and molecular mechanisms by which these contaminants affect the physiology of varying fish species in the St. Lawrence River. This information would provide a better understanding of the toxicity of the effluent and may help direct critical research avenues for understanding the impact of these contaminants on these fish. While other studies have examined the effects of MWWE on fish, differences in the composition of wastewater effluents due to differences in the industrial make-up of municipalities or treatment of effluents may alter different mechanisms by which physiological effects occur. The objectives of this study were to examine the effects of MWWE on gene expression in the liver of fathead minnow (Pimephales promelas), a species present in the St. Lawrence River, in order to identify key regulatory pathways implicated in the mechanism toxicity of MWWE. We elected to examine the liver, since it represents a site of action for many classes of contaminants can serve as a baseline for subsequent studies on other organ systems.

\section{Materials \& methods}

\subsection{Experimental protocol}

Fathead minnows were raised at the Quebec Aquarium (Québec, QC, Canada) and transferred to the Montreal wastewater treatment plant (Montreal, QC, Canada). Fish were maintained in $15 \mathrm{~L}$ glass aquariums with flowing water at a constant temperature $\left(25^{\circ} \mathrm{C} \pm 2{ }^{\circ} \mathrm{C}\right)$ under 16 $\mathrm{h}$ of light and $8 \mathrm{~h}$ of dark. Fish were fed $4 \mathrm{~mL}$ of brine shrimp (Ocean Nutrition, Dartmouth, NS, Canada) twice per day. Minnows ( $\mathrm{n}=6$ per group) were exposed for 21 days to either 0 (control) or $20 \% \mathrm{v} / \mathrm{v}$ wastewater effluent in a flow-through system. Each treatment condition was carried out in duplicate. Effluent concentrations corresponded to concentrations previously determined to be equivalent to those measured $0.3 \mathrm{~km}$ downstream from the discharge pipe in the St. Lawrence River (de Montgolfier et al., 2008). After 21 days, juvenile minnows were anesthetized in 3-aminobenzoic-ethyl-ester-acid (MS222; $0.05 \mathrm{~g} / \mathrm{L}$ ). Fish were euthanized, weighed, measured and livers were removed, weighed, frozen and stored at $-80{ }^{\circ} \mathrm{C}$. The sexual status, immature versus mature, of the fish was confirmed using a dissecting microscope. The condition factor of the fish was calculated according to Williams (2000). Only immature animals were used for subsequent analyses in order to minimize estrogen-induced changes in gene expression that would be apparent in adult fish. All animal procedures were approved by Environment Canada's Animal Care Committee according to the guidelines of the Canadian Council on Animal Care.

\subsection{RNA extraction}

Frozen liver samples were ground under liquid nitrogen using a mortar and pestle and total RNA was extracted using the Illustra RNAspin Mini kit (GE Healthcare, Baie D'Urfe, QC, Canada) according to the manufacturer's protocol. The quality of the RNA was verified using an RNA 6000 Nano kit (Agilent Technologies, Palo Alto, CA, USA) and Bioanalyzer model 2100 (Agilent Technologies). The isolated RNA was treated with DNase ( $1 \mathrm{U} / \mu \mathrm{g}$ of RNA, deoxyribonuclease I, amplification grade; GE Healthcare) to remove any contaminating genomic DNA. The RNA was then reverse transcribed using oligo $\mathrm{d}(\mathrm{T})$ 12-18 (R\&D Systems, Minneapolis, MS, USA) and M-MLV reverse transcriptase (Sigma Aldrich, Mississauga, ON, Canada), according to the suppliers' instructions.

\subsection{Microarray processing}

Gene expression profiling was carried out using a fathead minnow oligonucleotide array containing 15,208 oligonucleotides designed by EcoArray (Fat Head Minnow Microarray 016349, Alachua, FL, USA) and purchased from Agilent (Agilent Technologies). An aliquot of $500 \mathrm{ng}$ of total RNA was prepared for amplification and labeling with $\mathrm{Cy} 3$ using the Low RNA Input Linear Amplification kit and Quick Amp Labeling Kit, according to the manufacturer's instructions (Agilent Technologies). A $40 \mu \mathrm{L}$-aliquot of labeled cRNA was hybridized to each microarray according to the manufacturer's instructions using the In Situ Hybridization Kit Plus (Agilent Technologies). Following hybridization, the microarray slides were scanned using a ScanArray Express laser scanner (Perkin Elmer, Woodbridge, ON, Canada) and imported into Gene Pix Pro 7 (Molecular Devices Inc., Sunnyvale, CA, USA). Two slides, each containing 8 one-color microarrays, were used to hybridize RNA from control $(\mathrm{n}=4)$ and MWWE-exposed $(\mathrm{n}=4)$ fish.

\subsection{Microarray analysis}

Fluorescent images were processed using the GenePix Pro 7 software (Molecular Devices Inc.). Data were imported into GeneSpring GX11 software (Agilent Technologies) for further analysis. The intensity of each spot was characterized by the median pixel intensity and between-array scale normalization on median intensities was carried out using GeneSpring GX11 (Zahurak et al., 2007). Genes with a greater than 2-fold change in at least seven of the eight samples were included for further analysis. Analyses were done according to MIAME standards.

Network analysis and functional analysis (biological functions and biological/toxicological processes) of the differentially expressed genes with a greater than 4-fold change was carried out using Ingenuity Pathway Analysis (Ingenuity Systems, Redwood City, CA, USA). For these analyses, mammalian signaling pathways were considered to be similar to those in fish. Statistical analyses were carried out using a one-way ANOVA (significance level set at $\mathrm{p}<0.05$ ) using SigmaStat (SPSS Inc., Chicago, IL, USA).

\subsection{Western blot analyses}

Nuclear and cytosolic proteins were extracted from liver of control $(\mathrm{n}=5)$ and MWWE-exposed $(\mathrm{n}=4 ; 20 \% \mathrm{v} / \mathrm{v})$ fish using the Nuclear Extract kit (Active Motif, Carlsbad, CA, USA). Frozen tissue was homogenized with $3 \mathrm{~mL}$ of $1 \mathrm{X}$ Hypotonic Buffer (containing $3 \mu \mathrm{L}$ of $1 \mathrm{M}$ DTT and $3 \mu \mathrm{L}$ of detergent/g of tissue) and incubated on ice for $15 \mathrm{~min}$. 
Samples were centrifuged for $10 \mathrm{~min}$ at $850 \mathrm{~g}$ at $4{ }^{\circ} \mathrm{C}$ and the supernatant transferred to a chilled microcentrifuge tube. The pellet was resuspended in $500 \mu \mathrm{L}$ of $1 \mathrm{X}$ Hypotonic Buffer and incubated on ice for $15 \mathrm{~min}$. After incubation, $25 \mu \mathrm{L}$ of detergent was added to each sample and the tubes were vortexed for $10 \mathrm{~s}$. Samples were subsequently centrifuged for $45 \mathrm{~s}$ at $14000 \mathrm{~g}$ in a pre-cooled microcentrifuge $\left(4^{\circ} \mathrm{C}\right)$. The supernatant was used as the cytosolic fraction. The nuclear pellet was resuspended in $50 \mu \mathrm{L}$ of complete lysis buffer ( $10 \mathrm{mM}$ DTT, lysis buffer AM1 and protease inhibitor cocktail) and vortexed for $10 \mathrm{~s}$. The suspension was then incubated for $30 \mathrm{~min}$ on a rocking platform at $4{ }^{\circ} \mathrm{C}$. Samples were then vortexed for $10 \mathrm{~s}$ and centrifuged at $4{ }^{\circ} \mathrm{C}$ for $10 \mathrm{~min}$ at $14000 \mathrm{~g}$. The supernatant, containing the nuclear fraction, was then transferred to pre-cooled microcentrifuge tubes. Protein concentrations were determined using the Bradford protein assay (Bio-Rad Laboratories, Mississauga, ON, Canada). The purity of the nuclear fraction was determined using alpha-tubulin ( $\alpha$-tubulin) as a marker for the cytoplasmic fraction and histone protein $3(\mathrm{H} 3)$ as a marker for the nuclear fraction. Overexposed films showed $<7 \%$ cross-contamination between cytoplasmic and nuclear extracts. Aliquots of control and treated samples containing $25 \mu \mathrm{g}$ of nuclear proteins and $12.5 \mu \mathrm{g}$ of cytosolic protein were loaded onto a 4-20\% gradient gel (Bio-Rad Laboratories) and subjected to SDS-polyacrylamide gel electrophoresis (PAGE). Separated proteins were then transferred onto a nitrocellulose membrane at 100 $\mathrm{V}$ for $30 \mathrm{~min}$ and then at $80 \mathrm{~V}$ for $1 \mathrm{~h}$ at $4{ }^{\circ} \mathrm{C}$. The resulting membranes were stained with Ponceau red $\mathrm{S}$ to evaluate the transfer efficiency.

Membranes containing transferred proteins were blocked with phosphate-buffered saline (PBS) containing $5 \%$ powdered milk and $0.05 \%$ Tween and then hybridized overnight at $4{ }^{\circ} \mathrm{C}$ with the appropriate primary antibody (rabbit anti-H3, $6 \mathrm{ng} / \mathrm{mL}$, Cell Signalling Technology, Danvers, MA, USA; rabbit anti- $\beta$-catenin, 48 ng/mL, Cell Signalling Technology; rabbit anti-alpha-tubulin, 60-120 ng/mL, Abcam, Toronto, $\mathrm{ON}$, Canada). Following the hybridization, the membranes were washed in PBS containing $0.05 \%$ Tween and incubated for $1 \mathrm{~h}$ at room temperature with a horseradish peroxidase-conjugated anti-rabbit secondary antibody $(0.08 \mu \mathrm{g} / \mathrm{mL}$, Santa Cruz Biotechnology, Santa Cruz, CA, USA). The protein signal was revealed by chemiluminescence using a commercial kit (Lumilight, Roche Diagnostic, Laval, QC, Canada).

Protein loading was verified using Ponceau red (5\% Ponceau red in $5 \%$ acetic acid) coloration and quantified using a Fluor-S Multilmager (Bio-Rad Laboratories). A comparison of cytosolic and nuclear protein levels of CTNNB1 for control and treated samples was carried out. Cytoplasmic protein loading was standardized by measuring $\alpha$-tubulin levels and nuclear protein loading was standardized according to $\mathrm{H} 3$ levels. Since levels for these two proteins were not affected by treatment, they were considered appropriate loading controls.

\section{Results}

Fathead minnows were exposed to either dechlorinated tap water alone (control) or $20 \%$ wastewater effluent for 21 days. At the end of the exposure period there were no significant differences in either body weight, length, condition K-factor, or HSI between control and exposed fish (Table 1).

The fathead minnow oligonucleotide microarray used in this study contained 15208 genes. A total of 1300 genes were differentially expressed of which 309 genes were differentially expressed with a greater than 2-fold change in steady-state mRNA levels as compared

Table 1

Fish mass, length, condition K-factor and HSI in fish exposed top 20\% municipal effluent for 21 days. Control fish were exposed to dechlorinated tap water alone. There were no significant differences in between groups.

\begin{tabular}{lllll}
\hline Group & Mass $(\mathrm{g})$ & Length $(\mathrm{mm})$ & K-factor & HSI $(\%)$ \\
\hline Control & $3.10 \pm 0.17$ & $56.4 \pm 2.2$ & $1.74 \pm 0.12$ & $2.14 \pm 0.24$ \\
Exposed & $2.87 \pm 0.24$ & $58.8 \pm 0.9$ & $1.40 \pm 0.04$ & $2.30 \pm 0.32$ \\
\hline
\end{tabular}

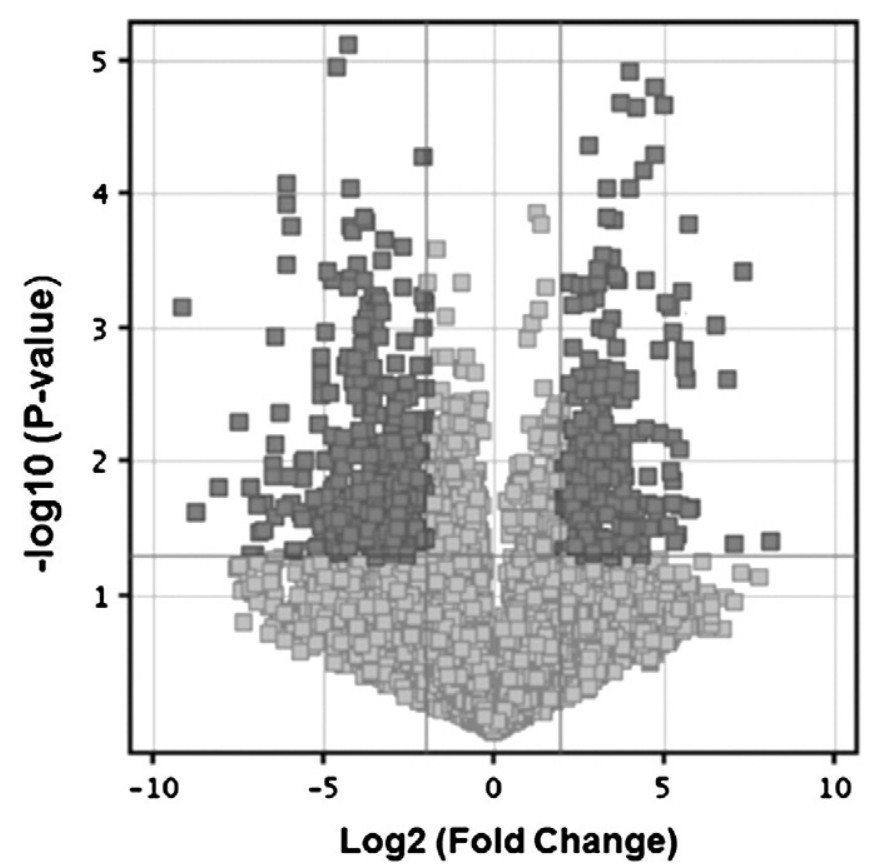

Fig. 1. Volcano plot of genes whose expression in the liver of control and MWWE-exposed minnows was found to be statistically significant (unpaired $t$-test) compared with their p-value. A total of 309 genes were differentially expressed. Of these genes, 118 were upregulated and 191 were down-regulated. Spots in dark gray were found to have a greater than 2-fold change and a p-value of less than 0.05 .

to controls (Fig. 1). Of the 309 differentially expressed genes, 118 were up-regulated and 191 were down-regulated. The data discussed in this publication have been deposited in NCBI's GEO (http://www. ncbi.nlm.nih.gov/geo (access number GSE52693)).

Mammalian homologues were identified for the differentially expressed genes and found to be associated with metabolism, development, signaling, cellular organization and assembly, and cell death (Fig. 2). Further analysis was conducted using differentially expressed genes with a greater than 4 -fold change: 17 genes were up-regulated and 18 genes were down-regulated (Tables 2 and 3). A large number of the up-regulated genes were implicated in cellular signaling,

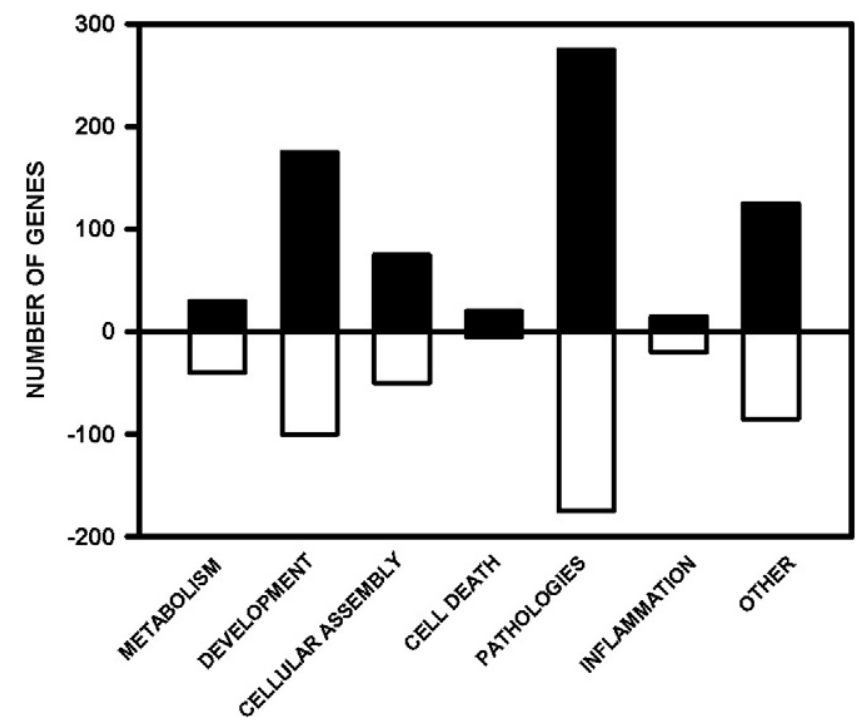

Fig. 2. Functional classification of differentially expressed genes by at least 2-fold in the liver of control and MWWE-exposed minnows. The genes were grouped based on their biological function. The bars in black represent the upregulated genes whereas the bars in white represent the downregulated genes. 
Table 2

List of up-regulated genes with a greater than 4 -fold change.

\begin{tabular}{llll}
\hline Gene ID & Gene symbol & Fold change & Gene function \\
\hline EA_Pp_62041a & MCAM & 10.15 & Cell adhesion, anatomical structure morphogenesis \\
EA_Pp_56813a & SIPA1L2 & 8.28 & Regulation of small GTPase mediated signal transduction \\
EA_Pp_52712a & SASH3 & 6.55 & Proliferation \\
EA_Pp_69607a & CPEB4 & 6.52 & Nucleotide binding \\
EA_Pp_58287a & MAGEA10 & 6.51 & May play a role in embryonal development and tumor transformation \\
EA_Pp_64305a & SLC40A1 & 5.82 & Ion transport, anatomical structure morphogenesis \\
EA_Pp_54032a & ATP6V0A2 & 5.53 & Ion transport, immune response, ATP synthesis coupled proton transport \\
EA_Pp_70960a & PDZRN3 & 5.13 & Protein ubiquitination \\
EA_Pp_57661a & PNOC & 5.09 & Signal transduction, neuropeptide signaling pathway, synaptic transmission, sensory perception \\
EA_Pp_56645a & DNAJC5 & 4.96 & Protein folding, negative regulation of neuron apoptosis \\
EA_Pp_69299a & KIAA0748 & 4.88 & Protein coding \\
EA_Pp_70787a & PHF13 & 4.63 & Transcription regulator \\
EA_Pp_59744a & TLCD1 & 4.62 & Integral to the membrane \\
EA_Pp_52997a & UBQLN4 & 4.46 & Cell death, negative regulation of transcription \\
EA_Pp_67710a & LCMT2 & 4.40 & tRNA processing \\
EA_Pp_57375a & C10orf27 & 4.37 & Multicellular organismal development, cell differentiation \\
EA_Pp_69299a & KIAA0319 & 4.31 & Cell adhesion \\
\hline
\end{tabular}

organization and development (Fig. 2). MCAM (melanoma cell adhesion molecule), SIPA1L2 (signal-induced proliferation-associated 1 like 2), SASH3 (SAM and SH3 domain containing 3) and MAGEA10 (melanoma antigen family A, 10) were the most highly up-regulated genes (Table 2). Of all of the differentially expressed genes, three functional groups, each containing a large number of altered genes were identified: These groups contained genes associated with cellular adhesion, inflammation and kinase activity (Fig. 3).

Altered genes involved in cellular adhesion included the downregulation of PCDHB7 (protocadherin beta 7), ARHGAP17 (Rho GTPase activating protein 17), HEPACAM (hepatic and glial cell adhesion molecule), RIKEN 2009E01, and the up-regulation of MCAM, PTK2 (protein tyrosine kinase 2), and L1CAM (L1 cell adhesion molecule) (Fig. 3). Down-regulated genes associated with inflammatory activities included MAVS (mitochondrial antiviral signaling protein), CXCR2 (chemokine (C-X-C motif) receptor 2), SMAD3 (SMAD family member 3), TNFSF11 (tumor necrosis factor (ligand) superfamily, member 11), AMBP (alpha1-microglobulin/bikunin precursor), ADAMTS (ADAM metallopeptidase with thrombospondin), and ATG16L1 (autophagy related 16-like 1; Fig. 3). Finally, the majority of genes involved in kinase activity were down-regulated, including ADPGK (ADP-dependent glucokinase), NME1 (NME/NM23 nucleoside diphosphate kinase 1), Raf-like, Aromatase (CYP19A1; cytochrome P450, family 19, subfamily A, polypeptide 1), AK8 (adenylate kinase 8), AKAP6 (A kinase anchor protein 6), PAK6 (p21 protein (Cdc42/Rac)-activated kinase 6), GUCY2C (guanylyl cyclase
2C), EPHA2 (EPH receptor A2), PHKA1 (phosphorylase kinase, alpha 1) and GAPDH (glyceraldehyde-3-phosphate dehydrogenase) with only one gene up-regulated, PFKL (phosphofructokinase) (Fig. 3).

At least ten genes that are known to be associated with the estrogen receptor signaling pathway were identified (Table 4). The majority of these genes were found to be down-regulated following exposure to MWWE. These genes included: SPOCK2 (spare/osteonectin, cWcV and kazal-like domains proteoglycan (testican) 2), HSPA5 (heat shock $70 \mathrm{kDa}$ protein 5), BNIP2 (BCL2/adenovirus E1B $19 \mathrm{kDa}$ interacting protein 2), NME1, PHKA1 (phosphorylase kinase alpha 1), CEP152 (centrosomal protein $152 \mathrm{kDa}$ ), and CBFA2T2 (core-binding factor, runt domain, alpha subunit 2; translocated to 2). Three of these genes were up-regulated including: DNAJC5 (DNACJ (Hsp40) homologue subfamily C member 5), NELL2 (NEL-like 2), and ENPEP (glutamyl aminoepeptidase). One gene involved in this pathway, VTG, was shown to have no change in expression levels.

Some genes (13) implicated in the Wnt/B-catenin signaling pathway were up-regulated in exposed fish as compared to controls. These included Wnt4 (Wingless-type MMTV integration site family, member 4), LRP6 (low density lipoprotein receptor-related protein 6), AES (amino-terminal enhancer of split), and PP2A/PP2R5E (ariadne homologue 2 ARIH2 and protein phosphatase 2, regulatory subunit B, epsilon isoform). Several other genes involved in this pathway were downregulated in treated fish when compared to controls. These included dapper antagonist of CTNNB1 homologue 1 (DACT1), KREMEN1 (kremen

Table 3

List of down-regulated genes with a greater than 4-fold change.

\begin{tabular}{llll}
\hline Gene ID & Gene symbol & Fold change & Gene function \\
\hline EA_Pp_54861a & FOXB1 & 11.63 & DNA dependent transcription regulation \\
EA_Pp_58527a & ADPGK & 11.47 & Carbohydrate metabolic process, glycolysis \\
EA_Pp_70091a & RACGAP1 & 10.71 & Transporter \\
EA_Pp_52153a & DCLRE1A & 8.57 & Nucleotide-excision repair \\
EA_Pp_50170a & TMEM63B & 7.15 & Protein binding \\
EA_Pp_53694a & TNFSF13 & 5.92 & Immune response, signal transduction, positive regulation of cell proliferation \\
EA_Pp_68848a & NME1 & 5.72 & Nervous system development, negative regulation of cell proliferation, cell differentiation, \\
& & & regulation of apoptosis \\
EA_Pp_68213a & DACT1 & 5.39 & Multicellular organismal development, Wnt receptor signaling pathway \\
EA_Pp_54650a & KREMEN1 & 5.33 & Cellular communication, Wnt receptor signaling pathway \\
EA_Pp_68856a & TIMM50 & 5.10 & Mitochondrial membrane organization, protein transport \\
EA_Pp_63441a & SKOR1 & 4.88 & Regulation of transcription, negative regulation of BMP signaling pathway \\
EA_Pp_55978a & UCHL3 & 4.80 & Ubiquitin-dependent protein catabolic process \\
EA_Pp_52942a & AMBP & 4.64 & Cell adhesion, negative regulation of immune response \\
EA_Pp_59061a & HEPACAM & 4.604 & Cell cycle, cell arrest, cell adhesion, regulation of growth \\
EA_Pp_55468a & TMEM151A & 4.55 & Integral to the membrane \\
EA_Pp_68927a & SGCD & 4.40 & Cytoskeleton organization, muscle organ development \\
EA_Pp_58058a & TTPAL & 4.38 & Transporter activity \\
EA_Pp_51446a & PBX3 & 4.08 & Transcription regulator \\
\hline
\end{tabular}




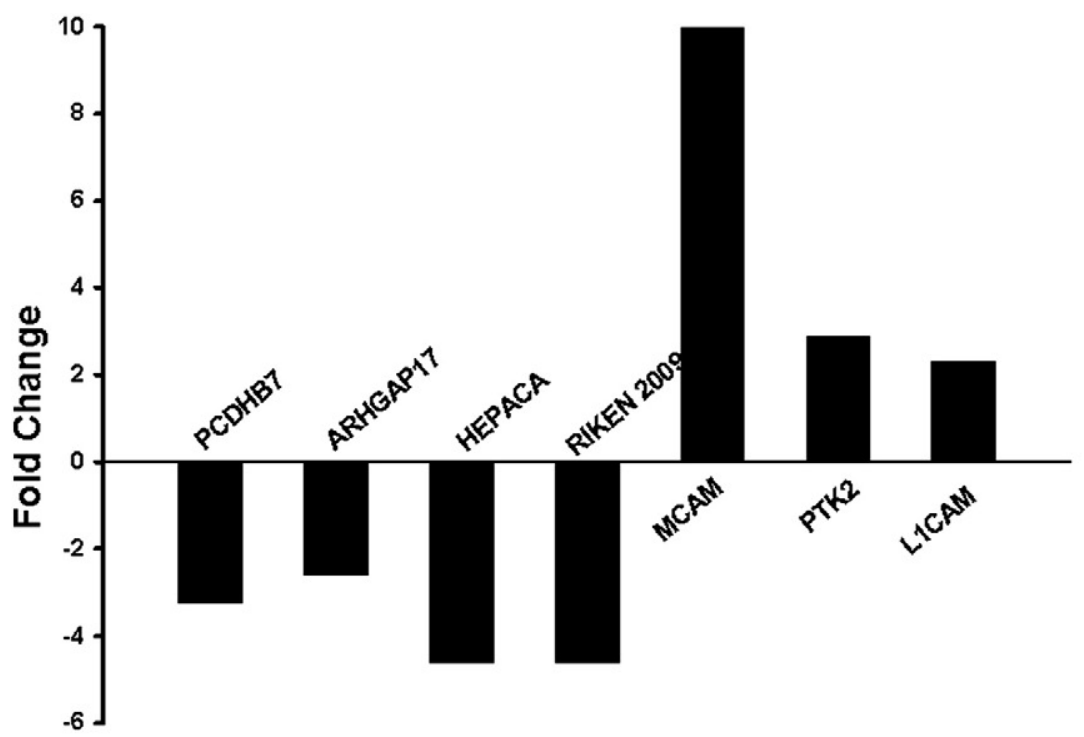

\section{Cell Adhesion}

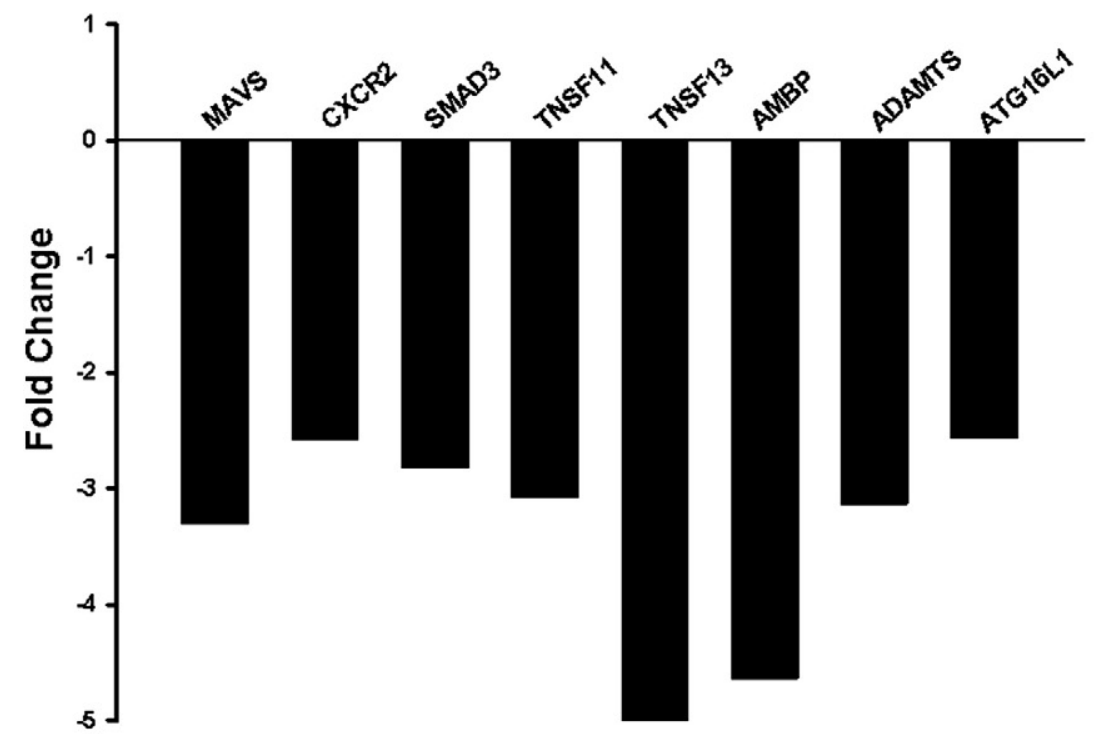

\section{Inflammation}

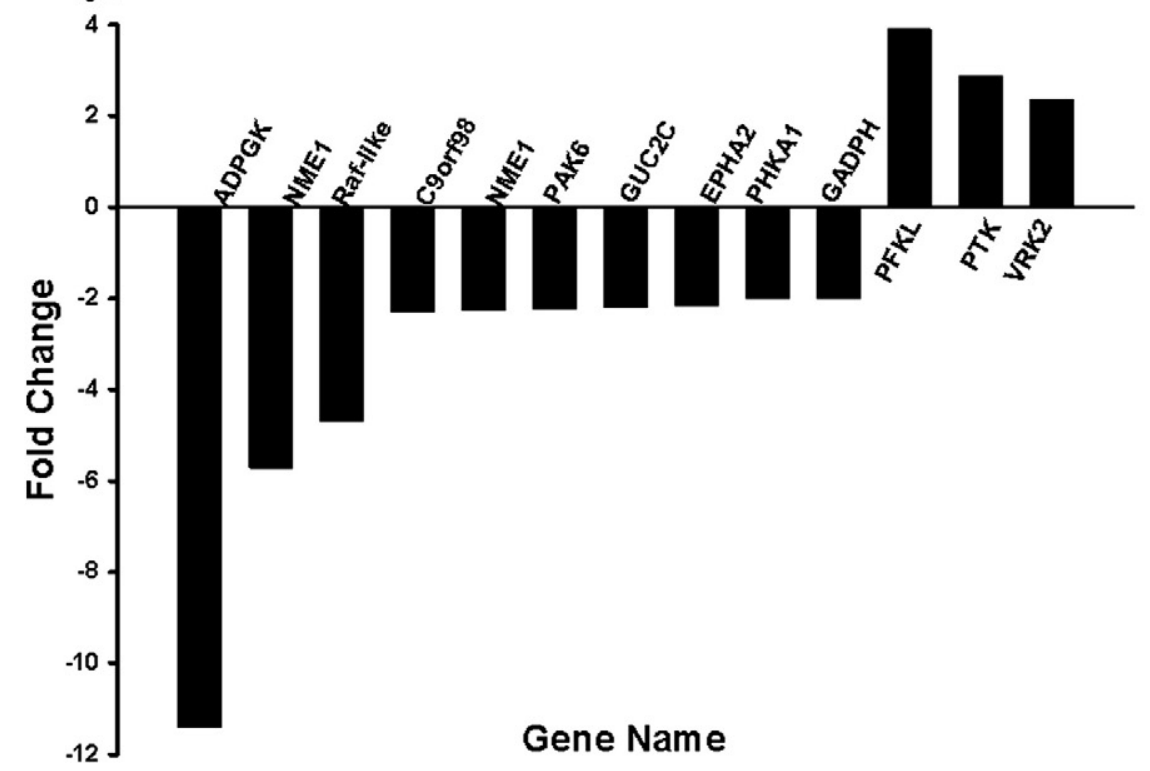

\section{Kinases}

Fig. 3. Differentially expressed genes in the liver of control and MWWE-exposed minnows grouped according to their function in cell adhesion. Inflammation and kinase activity. The upper panel represents mRNA levels for genes associated with cell adhesion; the middle panel B shows mRNA levels for genes associated with inflammation; the bottom panel shows mRNA levels for genes coding for different kinases. 
protein 1), GPR128 (G protein-coupled receptor 128), SKOR1 (SKI family transcriptional corepressor 1), SMAD3 (SMAD family member 3), FOXB1, SNIP2 (BCL2/adenovirus E1B $19 \mathrm{kDa}$ interacting protein), and NME1 (nucleoside diphosphate kinase A; Table 4).

To determine if the Wnt/B-catenin signaling pathway was altered at the protein level, we examined the levels of nuclear CTNNB1 in the liver of treated and control fish, since CTNNB1 is the key mediator in the canonical Wnt signaling pathway. CTNNB1 protein levels in both the cytosolic and nuclear fractions tended to be lower in MWWE-treated fish as compared to controls (Fig. 4).

\section{Discussion}

Exposure of fish to MWWE has been associated with a variety of physiological alterations, including reproductive and immune dysfunction. Pathway analysis software predicted at least 5 signaling pathways that were altered by treatment. These included pathways implicated in cell adhesion, inflammation, numerous kinases, estrogen receptor signaling and WNT signaling.

In vertebrates, adherens junctions, tight junctions and desmosomes, are responsible for epithelial integrity and the formation of immune-privileged sites within the body (Battle et al., 2006; Dubé and Cyr, 2012). In the present study, seven transcript coding for proteins implicated in cell adhesion were altered. Three of these genes (MCAM, PTK2 and L1CAM) were up-regulated, while four others were down-regulated (PCDHB7, ARHGAP17, HEPACAM and Riken 2009E01). Among these genes, PCDHB7 is a protocadherin which has been implicated in the establishment and function of specific cell-cell neural connections (Yagi and Takeichi, 2000). ARHGAP17 encodes for a protein involved in cell polarity and the maintenance of tight junctions by regulating the activity of CDC42. In mammals, ARHGAP17 is induced by GTPase-activating proteins (Kobayashi et al., 2013). HEPACAM has been shown to be down-regulated in many cancer cell lines and therefore may act as a tumor suppressor gene, due to its role in cell motility and cell-matrix interactions (Moh and Shen, 2009). In this study HEPACAM was down-regulated by almost 6-fold, suggesting that normal developmental functions that require cell motility and cell interactions were being inhibited (Moh and Shen, 2009). Another cell adhesion protein, RIKEN 209E01, responsible for hepatocyte cell adhesion was also down-regulated, further suggesting that cell adhesion and motility processes in the liver of MWWE-exposed fish were impaired. L1CAM, which was upregulated, is normally induced during development because of its role in axon guidance and cell migration (Dou et al., 2013). MCAM is a cell adhesion molecule that acts as a surface receptor that can trigger tyrosine phosphorylation of PTK2 and causes a transient increase in intracellular $\mathrm{Ca}^{2+}$ concentrations. Its induction has been shown to allow melanoma cells to interact with cellular elements of the vascular system, potentially increasing the spread of tumors (Chen et al., 2013; Ward et al., 2013). While the function of these genes in fish liver is largely unknown, alteration in cell adhesion suggests that epithelial function in the liver may be impaired and may predispose fish to other pathologies, including tumor development.

Studies have shown that fish exposed to mixtures of toxicants, similar to those found in MWWE, display altered immune function and an induction of the stress-related pathways (Hebert et al., 2008, b; Muller et al., 2009; Ings et al., 2011). Ings et al. (2011) sampled juvenile rainbow trout placed downstream from a municipal wastewater discharge pipe for 14 days (Ings et al., 2011). Using a cDNA microarray, a number of genes involved in immune response, including low molecular mass protein 2, major histocompatibility complex 1, Mx2 and Sox 24 were down-regulated, suggesting an inhibition of the immune system (Ings et al., 2011). A second study showed that juvenile rainbow trout exposed to $1 \%$ wastewater showed an increase in phagocytic activity after 28 days but a decrease in phagocytic activity after 90 days, suggesting that accumulation of toxicants can inhibit the immune response (Hebert et al., 2008). In this study, a number of genes implicated in the 
inflammatory response were decreased by exposure to municipal effluent. These included: MAVS, CXCR2, SMAD3, TNSF11, TNSF13, AMBP, ADAMTS, and ATG16L1. Several studies have reported that the immune system of aquatic organisms exposed to municipal wastewater effluent mixtures was altered (Hoole et al., 2003; Gagné et al., 2005, 2007, 2008; Bouchard et al., 2009; Gagné et al., 2012; Tetreault et al., 2012). In the present study, a number of cell-derived mediators of the inflammation response were down-regulated, including MAVS, which is required for the activation of transcription factors which regulate the expression of beta-interferon. During a stress response, leukocytes are mobilized towards toxicants, reducing the levels available within the organism. As well, CXCR2, a receptor for the cytokine interleukin 8 and chemokine ligand 1 , mediates neutrophil migration to sites of inflammation, suggesting a reduction of key mediators in the inflammatory pathway response. The inhibition of AMBP, a glycoprotein and ADAMTS, a peptidase, both play important roles in the regulation of inflammatory processes including tissue organization, coagulation, and cell migration. Finally, three genes involved in the T cell-dependent immune response, TNFSF11, TNFSF13 and ATG16L1, which play a role in cell-mediated immunity, were down-regulated. Overall, the present study showed a reduction in various aspects of the inflammation response, as shown by a reduction in proteins expressed by $\mathrm{T}$ cells, as well as by a decrease in cytokines and other key mediators. This decrease in immune/inflammation response points to a pre-disposition to infection and possibly other pathogenic attack, thus reducing the overall health of both the individual fish, and more alarmingly, pointing to a reduction in the health of the fish population.

Several gene transcripts for protein kinases were also altered byexposure to MWWE. Ten genes in the present study were downregulated, including ADPGK, NME1, Raf-like, AK8, AKAP6, PAK6, GUCY2C, EPHA2, PHKA1, and GAPDH, while PFKL, PTK and VRK2 were upregulated (Table 4; Fig. 4). ADPGK is responsible for the catalyzing ADP-dependent phosphorylation of glucose to glucose-6-phosphate in the glycolytic cycle. GAPDH catalyzes the breakdown of glucose for energy and carbon molecules (Tarze et al., 2007). It has also recently been implicated in several non-metabolic processes, including transcription activation and initiation of apoptosis (Tarze et al., 2007). AK8 is a phosphotransferase enzyme that catalyzes the interconversion of adenine nucleotides that play a role in cellular energy homeostasis. The PAK6 gene encodes for an enzyme implicated in the regulation of a number of cellular processes, including cytoskeleton rearrangement, apoptosis, and MAP kinase signaling (Ye and Field, 2012; Furnari et al., 2013). As well, PAK6 interacts with the androgen receptor, which is important for male sexual differentiation and development (Lee et al., 2002), although this is unlikely involved in liver function. An overall inhibition of kinase activity observed in this study suggests that various intracellular signaling pathways may be directly targeted by exposure to MWWE, again negatively impacting various metabolic processes, as well as sexual differentiation and development. It is likely that the alterations in genes comprising these pathways may be responsible, in part, for some of the effects previously reported in fish or hepatocytes exposed to MWWE (Gagné and Blaise, 1995; Aravindakshan et al., 2004; de Montgolfier et al., 2008).

Analyses of gene expression data indicated that 13 estrogen (E2)regulated genes were altered after exposure to MWWE. These genes are involved in numerous cellular functions and have been shown in mammals to be regulated either directly or indirectly by estradiol. Genes that are estrogen-dependent and whose expression was decreased by exposure WWWE included NELL2, HSPA5, SPOCK2 and BNIP2 (Belcredito et al., 2001; Watanabe et al., 2003; Ivanga et al., 2007; Choi et al., 2010; Guzel et al., 2011). Furthermore, eight genes shown to be regulated downstream of the E2 receptor including
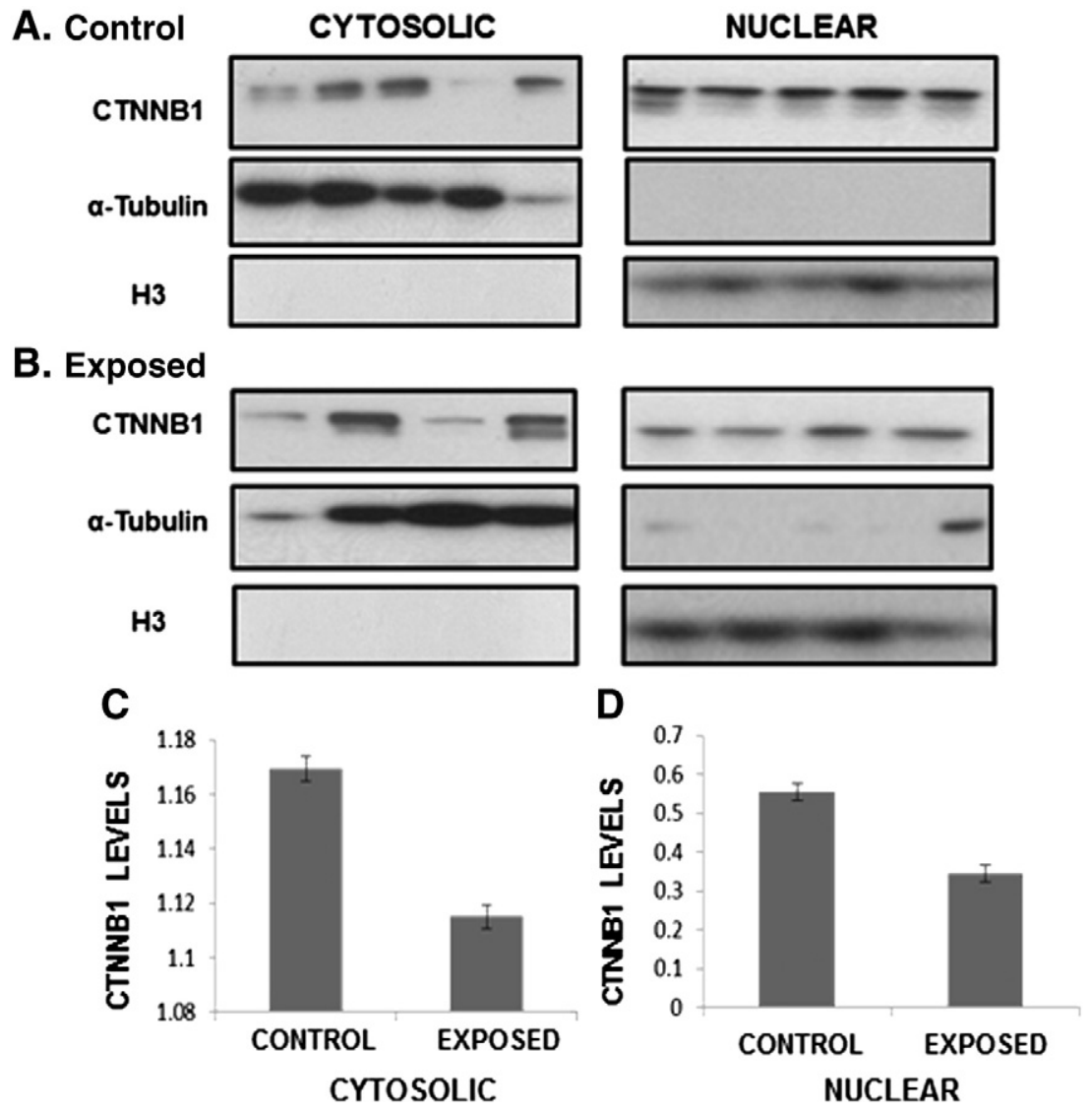

Fig. 4. Western blot analysis of CTNNB1 protein expression in fathead minnow exposed to MWWE as compared with controls. Cytosolic protein loading was standardized using $\alpha$-tubulin as a protein loading control (Panels A and B) and nuclear protein loading was standardized using H3 as a protein loading control (Panels C and D). Data are expressed as the mean \pm SEM. 
ENPEP, DNAJC5, PLXNA3, and UBQLN4 were also down-regulated. Aromatase, a member of the cytochrome P450 superfamily, and a key enzyme in the biosynthesis of estrogens, was down-regulated in the liver of MWWE-exposed fish in the present study. Inhibition of aromatase suggests a reduction in the synthesis of the hormone estrogen, a key hormone for both sexual differentiation and morphogenesis (Cooke and Naaz, 2004; McCarthy and Knokle, 2005).

While the data suggest an inhibition of the estrogenic pathway, it should be noted that estradiol levels in these immature fish are likely to be very low, and thus the significance of this is unknown, nor can we draw any conclusions at this time on the potential response of these fish to E2. Previous studies have shown that in brook trout, VTG mRNA induction in male and juvenile fish occurred after only 12 weeks of exposure (de Montgolfier et al., 2008) suggesting the need for contaminants to accumulate in these fish prior to the induction of an estrogenic response. The present data would support these conclusions.

A number of genes involved in the Wnt/CTNNB1 signaling pathway were differentially expressed in MWWE-exposed fathead minnows. Wnt signaling is implicated in numerous critical cellular functions including cell-cell signaling during embryogenesis, cellular differentiation, cell adhesion, cell cycle progression and differentiation (Hendriks and Reichmann, 2002; Monga and Michalopoulos, 2005).

Wnt signaling is also involved in liver development, cell proliferation, apoptosis and tissue homeostasis (Logan and Nusse, 2004; Lu et al., 2011). Several genes in the canonical Wnt pathway, including KREMEN1, Frizzled, DACT1, and DVL2 (disheveled dsh homologue 2), were dramatically down-regulated. The Wnt pathway can be activated either when the Fz-LRP complex is formed or with the autophosphorylation of LRP6; both actions send a signal through intermediate proteins to activate Dsh (disheveled) (Veeman et al., 2003; Monga and Michalopoulos, 2005; Lade and Monga, 2011). Dsh then blocks CTNNB1 degradation by recruiting GSK3B, allowing the axin APC complex to form and inactivating CTNNB1 ubiquitination (Veeman et al., 2003; Monga and Michalopoulos, 2005; Lade and Monga, 2011). Dkk-1 interacts with LRP5/ 6 and the co-receptor KREMEN1 to prevent the formation of the LRP5/6-Wnt-Frizzled complex (Osada et al., 2006). In the present study, KREMEN1 was down-regulated, suggesting a reduction in the formation of the LRP5/6 Wnt-Frizzled complex (Cadoret et al., 2002; Davidson et al., 2002; Mao et al., 2002; Osada et al., 2006). DACT1 binds to Dsh and impedes the degradation of CTNNB1, enhancing the transcriptional activity of genes targeted by the Wnt pathway. In this study, fathead minnows exposed to MWWE exhibited a downregulation of DACT1, suggesting that one mechanism of controlling CTNNB1 levels was inhibited. Dsh signaling through the Wnt pathway can be transduced by one of two routes depending on the target gene and end function. Several other genes involved in the non-canonical Wnt pathway, such as Wnt4, LRP6, and PPP2R5E (Serine/threonineprotein phosphatase 2A $56 \mathrm{kDa}$ regulatory subunit epsilon isoform), which are known to inhibit the canonical Wnt pathway, were also increased. Wnt4 has been shown to inhibit Wnt signaling to the nucleus by redirecting CTNNB1 to the plasma membrane (Bernard et al., 2008). Thus the increase in Wnt4 may decrease overall Wnt signaling via the canonical Wnt signaling pathway. Exposed minnows in this study showed higher levels of LRP6 mRNA. The role of LRP6 in Wnt signaling has been reported to be either stimulatory or inhibitory. Activation of Wnt signaling can occur when LRP6 inhibits GSK3 $\beta$ (Metcalfe and Bienz, 2011), resulting in increased CTNNB1 in the cytosol and subsequent translocation to the nucleus, where it can act as a transcription factor (Fang et al., 2000). However, LRP can also interact with DKK1, which can then inhibit Wnt signaling. Since LRP6 was increased in MWWE-exposed fish, this may also contribute to the inhibition of the WNT pathway.

In the absence of Wnt signaling, APC, axin and GSK3 phosphorylate CTNNB1 marking it for degradation by an E3 ubiquitination protein
(Polakis, 2001; Hendriks and Reichmann, 2002). In this study fish exposed to MWWE showed an increase in three E3 ubiquitination proteins: ARIH2, TOPORS (topoisomerase I binding arginine serinenich) and UBQLN4 (ubiquilin 4). A lack of Wnt signaling in the nucleus could act as a repressor of target gene transcription in conjunction with the co-repressor Groucho/AES (Monga and Michalopoulos, 2005). Two Wnt pathway inhibitors, AES and PPP2R5E (phosphatase 2A) were also up-regulated in these fish, further supporting an inhibition of the canonical Wnt signaling pathway. The decrease in Wnt signaling was supported by the results of the Western blot, which suggested a decrease in both cytosolic and nuclear Wnt protein levels in the livers of fish exposed to MWWE.

Other studies have reported that components of the Wnt $/ \beta$ catenin signaling pathway may be altered following exposure to environmental contaminants. Ung et al. (2010) reported that in zebrafish, $\mathrm{HgCl}_{2}$ exposure induced GSK3 mRNA and decreased levels of cadherin1 (also known as E-cadherin) immunostaining. In another study, Mirbahai et al. (2011) collected dab from five sampling sites along the Irish Sea and Bristol Channel and compared healthy livers with those showing lesions and/or hepatocellular carcinoma. Livers of fish sampled from two of the sampling sites, which contained elevated levels of polychlorinated biphenyl, polybrominated diphenyl ethers, and heavy metals such as cadmium and lead (Mirbahai et al., 2011), displayed altered DNA methylation of genes implicated in the Wnt/ß-catenin signaling pathway (Mirbahai et al., 2011). These included Dsh, Frz, and the tumor suppressor gene APC (adenomatous polyposis coli) and c-myc, a TCF/LEF regulated gene. Previous studies from our laboratory have shown that in rats treated with hexachlorobenzene, there is an activation of WNT signaling and increased translocation of CTNNB1 to the nucleus (Plante et al., 2005). This is associated with decreased levels of Cx43, Cx32 and Cx26 (Plante et al., 2002). While we have shown that short-term exposure of brook trout to MWWE can result in a slight decrease in testicular $\mathrm{Cx} 43$ and Cx43.1 (de Montgolfier et al., 2008), further studies will be needed to establish a link between Wnt signaling and changes in Cx levels in the testis. The present study is the first to suggest an alteration in Wnt/ $\beta$ catenin signaling in fish exposed to MWWE.

Together, results from the present study suggest that short-term exposure to MWWE results in an inhibition of estrogenic signaling and Wnt signaling pathways.

Signaling pathway analyses suggest that other pathways mediated by several kinases and inflammation are also targeted following exposure to MWWE, and likely result in a variety of altered physiological functions. The effects on Wnt signaling are particularly interesting and suggest that in addition to effects in juveniles and adults, the effluent may exert significant effects during embryonic development or in the development of pathological conditions, when Wnt signaling plays an important role in cellular differentiation and development. This would also suggest the potential for abnormal development as well as leading to embryonic death, parameters that have not been examined in MWWE-exposed fish. Such effects would have significance both for individual, as well as for the fish populations living downstream from the MWWE point of discharge.

\section{Acknowledgments}

Mr. Patrick Cjeka (City of Montreal, deceased) is thanked for his assistance and support of our research program on municipal wastewater effluent. Fathead minnow exposure to the municipal effluent was performed at the Station Plant of Montréal (QC, Canada) by Sophie Trépanier. Mary Gregory (INRS) is thanked for her helpful suggestions. This work was supported by grants from NSERC (155065-06), the Canadian Water Network, Fonds de Recherches Santé du Québec-Réseau de recherches en santé environnementale to DGC and from Environment Canada to FG. 


\section{References}

Aravindakshan, J., Paquet, V., Gregory, M., Dufresne, J., Fournier, M., Marcogliese, D.J., Cyr, D.G., 2004. Consequences of xenoestrogen exposure on male reproductive function in spottail shiners (Notropis hudsonius). Toxicol. Sci. 78, 156-165.

Battle, M.A., Konopka, G., Parviz, F., Gaggl, A.L., Yang, C., Sladek, F.M., Duncan, S.A., 2006. Hepatocyte nuclear factor 4alpha orchestrates expression of cell adhesion proteins during the epithelial transformation of the developing liver. Proc. Natl. Acad. Sci. U. S. A. $103,8419-8424$

Belcredito, S., Vegeto, E., Brusadelli, A., Ghisletti, S., Mussi, P., Ciana, P., Maggi, A., 2001. Estrogen neuroprotection: the involvement of the Bcl-2 binding protein BNIP2. Brain Res. Rev. 37, 335-342.

Bernard, P., Fleming, A., Lacombe, A., Harley, V.R., Vilain, E., 2008. Wnt4 inhibits beta-catenin/TCF signalling by redirecting beta-catenin to the cell membrane. Biol. Cell. 100, 167-177.

Bouchard, B., Gagné, F., Fortier, M., Fournier, M., 2009. An in-situ study of the impacts of urban wastewater on the immune and reproductive systems of the freshwater mussel Elliptio complanata. Comp. Biochem. Physiol. C Toxicol. Pharmacol. 150, 132-140.

Cadoret, A., Ovejero, C., Terris, B., Souil, E., Levy, L., Lamers, W.H., Kitajewski, J., Kahn, A., Perret, C., 2002. New targets of beta-catenin signalling in the liver are involved in the glutamine metabolism. Oncogene 21, 8293-8301.

Chambers, P.A., Allard, M., Walker, S.L., Marsalek, J., Lawrence, J., Servos, M., Busnarda, J., Munger, K.S., Adare, K., Jefferson, C., Kent, R.A., Wong, M.P., 1997. Impacts of municipal wastewater effluents on Canadian waters: a review. Water Qual. Res. J. Can. 32, 659-713.

Chen, Q., Chen, L., Zhao, R., Yang, X.D., Imran, K., Xing, C.G., 2013. Microarray analyses reveal liver metastasis-related genes in metastatic colorectal cancer cell model. J. Cancer Res. Clin. Oncol. 139, 1169-1178.

Choi, E.J., Kim, D.H., Kim, J.G., Kim, D.Y., Kim, J.D., Seol, O.J., Jeong, C.S., Park, J.W., Choi, M.Y., Kang, S.G., Costa, M.E., Ojeda, S.R., Lee, B.J., 2010. Estrogen-dependent transcription of NEL-like 2 (NELL2) gene and its role in protection from cell death. J. Biol. Chem. 285, 25074-25084.

Cooke, P.S., Naaz, A., 2004. Role of estrogens in adipocyte development and function. Exp. Biol. Med. 229, 1127-1135.

Cyr, D.G., Lee, K.H., Marcogliese, D.J., Sanderson, J.T., 2014. Recent advances in endocrine disruptors. In: Blaise, C., Ferrard, J.F. (Eds.), Encyclopedia of Aquatic Toxicology. Elsevier, New York, pp. 781-796.

Davidson, G., Mao, B., del Barco Barrantes, I., Niehrs, C., 2002. Kremen proteins interact with Dickkopf1 to regulate anteroposterior CNS patterning. Development 129, 5587-5596.

de Montgolfier, B., Fournier, M., Audet, C., Marcogliese, D.J., Cyr, D.G., 2008. Influence of municipal effluents on the expression of connexions in the brook trout (Salvelinus fontinalis) testis. Aquat. Toxicol. 86, 38-48.

Dou, W., Zhang, J., Sun, A., Zhang, E., Ding, L., Mukherjee, S., Wei, X., Chou, G., Wang, Z.T., Mani, S., 2013. Protective effect of naringenin against experimental colitis via suppression of Toll-like receptor 4/NF-kB signalling. Br. J. Nutr. 110, 599-608.

Dubé, É., Cyr, D.G., 2012. The blood-epididymis barrier. In: Cheng, C.Y. (Ed.), Biology and Regulation of Blood-Tissue Barriers. Landes Bioscience, New York, NY, pp. 218-236.

Escarné, R., Gagné, F., Dautremepuits, C., Cyr, D.G., Finnson, K., Marcogliese, D.J., Bernier, J., Cejka, P., Fournier, M., 2008. Effects of municipal sewage effluent on non-specific immune and thyroid functions of rainbow trout (Oncorhyncus mykiss). Trends Comp. Biochem. Physiol. 13, 27-39.

Fang, X., Yu, S.X., Lu, Y., Bast Jr., R.C., Woodgett, J.R., Mills, G.B., 2000. Phosphorylation and inactivation of glycogen synthase kinase 3 by protein kinase A. Proc. Natl. Acad. Sci. U. S. A. 97, 11960-11965

Furnari, M.A., Jobes, M.L., Nekrasova, T., Minden, A., Wagner, G.C., 2013. Functional deficits in PAK5, PAK6 and PAK5/PAK6 knockout mice. PLoS ONE 8, e61321.

Gagné, F., Blaise, C., 1995. Fluorescent in situ hybridization en suspension (FISHES) procedure using biotin-labelled DNA probes for measuring genetic expression of metallothionein and cytochrome P-450 IA1 in rainbow trout hepatocytes exposed to wastewaters. In: Richardson, M. (Ed.), Environmental Toxicology Assessment. Taylor \& Francis, London, pp. 41-54.

Gagné, F., Blaise, C., Aoyama, I., Luo, R., Gagnon, C., Couillard, Y., Campbell, P., Salazar, M., 2002. Biomarker study of a municipal effluent dispersion plume in 2 species of freshwaster mussels. Environ. Toxicol. 17, 149-159.

Gagné, F., Berube, E., Fournier, M., Blaise, C., 2005. Inflammatory properties of municipal effluents to Elliptio complanata mussels-lack of effects from anti-inflammatory drugs. Comp. Biochem. Physiol. C Toxicol. Pharmacol. 141, 332-337.

Gagné, F., Andre, C., Cejka, P., Gagnon, C., Blaise, C., 2007. Toxicological effects of primarytreated urban wastewaters, before and after ozone treatment, on freshwater mussels (Elliptio complanata). Comp. Biochem. Physiol. C Toxicol. Pharmacol. 145, 542-552.

Gagné, F., Andre, C., Cejka, P., Hausler, R., Fournier, M., Blaise, C., 2008. Immunotoxic effects on freshwater mussels of primary-treated wastewater before and after oxonation: a pilot plant study. Ecotoxicol. Environ. Saf. 69, 366-373.

Gagné, F. Andre, C., Fortier, M., Fournier, M., 2012. Immunotoxic potential of aeration lagoon effluents for the treatment of domestic and hospital wastewaters in the freshwater mussel Elliptio complanata. J. Environ. Sci. (China) 24, 781-789.

Gregory, M., Aravindakshan, J., Nadzialeck, S., Cyr, D.G., 2008. Effects of endocrine disrupting chemicals on male reproduction. In: Alavi, H., Raffiee, R., Cosson, J., Coward, K. (Eds.), Fish Spermatology. Narosa Publish House, New Dehli, pp. 161-214.

Guzel, E., Basar, M., Ocak, N., Arici, A., Kayisli, U.A., 2011. Bidirectional interaction between unfolded-protein-response key protein HSPA5 and estrogen signalling in human endometrium. Biol. Reprod. 85, 121-127.

Hebert, N., Gagné, F., Cejka, P., Cyr, D., Marcogliese, D.J., Blaise, C., Pellerin, J., Fournier, M., 2008. The effects of a primary-treated municipal effluent on the immune system of rainbow trout (Oncorhynchus mykiss): exposure duration and contribution of suspended particles. Comp. Biochem. Physiol. C Toxicol. Pharmacol. 148, 258-264.

Hendriks, B., Reichmann, E., 2002. Wnt signalling: a complex issue. Biol. Res. 35, 1-9.

Hoole, D., Lewis, J.W., Schuwerack, P.M., Chakravarthy, C., Shrive, A.K., Greenhough, T.J., Cartwright, J.R., 2003. Inflammatory interactions in fish exposed to pollutants and parasites: a role for apoptosis and C reactive protein. Parasitology 126, S71-S85.

Houde, M., Douville, M., Despatie, S., De Silva, A.O., Spencer, C., 2013. Induction of gene responses in St. Lawrence River northern pike (Esox lucius) environmentally exposed to perfluorinated compounds. Chemosphere. http://dx.doi.org/10.1016/j.chemosphere. 2013.01.099.

Ings, J.S., Servos, M.R., Vijayan, M.M., 2011. Hepatic transcriptomics and protein expression in rainbow trout exposed to municipal wastewater effluent. Environ. Sci. Technol. 45, 2368-2376.

Ivanga, M., Labrie, Y., Calvo, E., Belleau, P., Martel, C., Luu-The, V., Morissette, J., Labrie, F. Durocher, F., 2007. In uterus from female mouse missing a ovary, E2 is involved in expression of mouse SPOCK2 mRNA. Physiol. Genomics 29, 13-23.

Jobling, S., Nolan, M., Tyler, C.R., Brighty, G., Sumpter, J.P., 1998. Widespread sexual disruption in wild fish. Environ. Sci. Technol. 32, 2498-2506.

Jobling, S., Beresford, N., Nolan, M., Rodgers-Gray, T., Brighty, G.C., Sumpter, J.P., Tyler, C.R 2002. Altered sexual maturation and gamete production in wild roach (Rutilus rutilus) living in rivers that receive treated sewage effluents. Biol. Reprod. 66, 272-281.

Kobayashi, Y., Harada, A., Furuta, B., Asou, H., Kato, U., Umeda, M., 2013. The role of NADRIN, a Rho GTPase-activating protein, in the morphological differentiation of astrocytes. J. Biochem. 153, 389-398.

Lade, A.G., Monga, S.P., 2011. Beta-catenin signalling in hepatic development and progenitors: which way does the WNT blow? Dev. Dyn. 240, 486-500.

Lee, S.R., Ramos, S.M., Ko, A., Masiello, D., Swanson, K.D., Lu, M.L., Balik, S.P., 2002. AR and ER interaction with a p21-activated kinase (PAK6). Mol. Endocrinol. 16, 85-99.

Logan, C.Y., Nusse, R., 2004. The Wnt signalling pathway in development and disease. Annu. Rev. Cell Dev. Biol. 20, 781-810.

Lu, J.W., Hsia, Y., Tu, H.C., Hsia, Y.C., Yang, W.Y., Wang, H.D., Yuh, C.H., 2011. Liver development and cancer formation in zebrafish. Birth Defects Res. C Embryo Today 93 $157-172$.

Mao, B., Wu, W., Davidson, G., Marhold, J., Li, M., Mechler, B.M., Delius, H., Hoppe, D. Stannek, P., Walter, C., Glinka, A., Niehrs, C., 2002. Kremen proteins are Dicckopf receptors that regulate Wnt/beta-catenin signalling. Nature 417, 664-667.

Marcogliese, D.J., Gendron, A., Plante, C., Fournier, M., Cyr, D.G., 2006. Parasites of spottail shiners (Notropis hudsonius) in the St. Lawrence River: effects of municipal effluents, habitat and biodiversity. Can. J. Zool. 84, 1461-1481.

Marcogliese, D., Gendron, A.D., Cone, D.K., 2009. Impact of municipal effluents and hydrological regime on myxozoan parasite communities of fish. Int. J. Parasitol. 39, 1345-1351.

McCarthy, M.M., Knokle, A.T., 2005. When is a sex difference not a sex difference? Front. Neuroendocrinol. 26, 85-102.

Ménard, L., Escarné, R., Marcogliese, D.J., Cyr, D.G., Fournier, M., Gagné, F., 2010. The impacts of urban pollution on the immune system of spottail shiners (Notropis hudsonius) in the St. Lawrence. Fresenius Environ. Bull. 19, 1369-1374.

Metcalfe, C., Bienz, M., 2011. Inhibition of GSK3 by Wnt signalling two contrasting models. J. Cell Sci. 124, 3537-3544.

Mirbahai, L., Yin, G., Bignell, J.P., Li, N., Williams, T.D., Chipman, J.K., 2011. DNA methylation in liver tumorigenesis in fish from the environment. Epigenetics 6, 1319-1333.

Moh, M.C., Shen, S., 2009. The roles of cell adhesion molecules in tumor suppression and cell migration: a new paradox. Cell Adhes. Migr. 3, 334-336.

Monga, S.P.S., Michalopoulos, G.K., 2005. The Wnt/ß-catenin pathway. In: Dufour, J., Clavien, P.A. (Eds.), Signalling in Liver Diseases. Springer-Verlag, New York, NY pp. $173-192$

Muller, C. Ruby, S., Brousseau, P., Cyr, D., Fournier, M., Gagné, F., 2009. Immunotoxicologica effects of an activated-sludge-treated effluent on rainbow trout (Oncorhynchus mykiss). Comp. Biochem. Physiol. C Toxicol. Pharmacol. 150, 390-394.

Osada, M., Ito, E., Fermin, H.A., Vazquez-Cintron, E., Venkatesh, T., Friedel, R.H., Pezzano, M., 2006. The Wnt signalling antagonist Kremen1 is required for development of thymic architecture. Clin. Dev. Immunol. 13, 299-319.

Pham, T.T., Proulx, S., 1997. PCBs and PAHs in the Montreal Urban Community (Quebec, Canada) wastewater treatment plant and in the effluent plume in the St. Lawrence River. Water Res. 31, 1887-1896.

Plante, I., Charbonneau, M., Cyr, D.G., 2002. Gender-specific hepatic tumour promotion by hexachlorobenzene may be mediated by alteration in gap junctions. Carcinogenesis 23, 1243-1249.

Plante, I., Cyr, D.G., Charbonneau, M., 2005. Involvement of the integrin-linked kinase pathway in Hexachlorobenzene-induced gender-specific rat hepatocarcinogenesis. Toxicol. Sci. 88, 346-357.

Polakis, P., 2001. More than one way to skin a catenin. Cell 105, 563-566.

Sabik, H., Gagné, F., Blaise, C., Marcogliese, D.J., Jeannot, R., 2003. Occurrence of alkylphenol polyethoxylates in the St. Lawrence River and their bioconcentration by mussels (Elliptio complanata). Chemosphere 51, 349-356.

Salo, H.M., Hebert, N., Dautremepuits, C., Cejka, P., Cyr, D.G., Fournier, M., 2007. Effects of Montreal municipal sewage effluents on immune responses of juvenile female rainbow trout (Oncorhynchus mykiss). Aquat. Toxicol. 84, 406-414.

Tarze, A., Deniaud, A., Le Bras, M., Maillier, E., Molle, D., Larocheete, N., Zamzami, N., Jan, G., Kroemer, G., Brenner, C., 2007. GAPDH, a novel regulator of the pro-apoptotic mitochondrial membrane permeabilization. Oncogene 26, 2606-2620.

Tetreault, G.R., Bennett, C.J., Cheng, C., Servos, M.R., McMaster, M.E., 2012. Reproductive and histopathological effects in wild fish inhabiting an effluent-dominated stream, Wascana Creek, SK., Canada. Aquat. Toxicol. 110-111, 149-161.

Thorpe, K.L., Maak, G., Benstead, R., Tyler, C.R., 2009. Estrogenic wastewater treatment works effluent reduce egg production in fish. Environ. Sci. Technol. 43, 2976-2982. 
Ung, C.Y., Lam, S.H., Hlaing, M.M., Korzh, S., Mathavan, S., Gong, Z., 2010. Mercury-induced hepatotoxicity in zebrafish: in vivo mechanistic insights from transcriptome analysis, phenotype anchoring and targeted gene expression validation. BMC Genomics 11 212-228.

Veeman, M.T., Axelrod, J.D., Moon, R.T., 2003. A second canon: functions and mechanisms of $\beta$-catenin-independent Wnt signalling. Dev. Cell 5, 367-377.

Vidal-Dorsch, D.E., Bay, S.M., Maruya, K., Synder, S.A., Trenholm, R.A., Vanderford, B.J. 2012. Contaminants of emerging concern in municipal wastewater effluents and marine receiving water. Environ. Toxicol. Chem. 31, 2674-2682.

Ward, K.K., Tancioni, I., Lawson, C., Miller, N.L., Jean, C., Chen, X.L., Uryu, S., Kim, J., Tarin, D. Stupack, D.G., Plaxe, S.C., Schlaepfer, D.D., 2013. Inhibition of focal adhesion kinase (FAK) activity prevents anchorage-independent ovarian carcinoma cell growth and tumor progression. Clin. Exp. Metastasis 30, 579-594.
Watanabe, H., Suzuki, A., Kobayashi, M., Lubahn, D.B., Handa, H., Iguchi, T., 2003. Similarities and differences in uterine gene expression patterns caused by treatment with physiological and non-physiological estrogens. J. Mol. Endocrinol. 31, 487-497.

Williams, J.E., 2000. The coefficient of condition of fish. In: Schneider, J.C. (Ed.), Manual of Fisheries Survey Method II: With Periodic Updates. Michigan Department of Natural Resouces, Fisheries Special Report, 25, pp. 1-2 (Ann Arbor. Chapter 13).

Yagi, T., Takeichi, M., 2000. Cadherin superfamily genes: functions, genomic organization, and neurologic diversity. Genes Dev. 14, 1169-1180.

Ye, D.Z., Field, J., 2012. PAK signalling in cancer. Cellular Logistics, 2. Landes Bioscience Inc. pp. 105-116.

Zahurak, M., Parmigiani, G., Yu, W., Scharpf, R.B., Berman, D., Schaeffer, E., Shabbeer, S., Cope, L., 2007. Pre-processing Agilent microarray data. BMC Bioinforma. 8, $142-155$ 